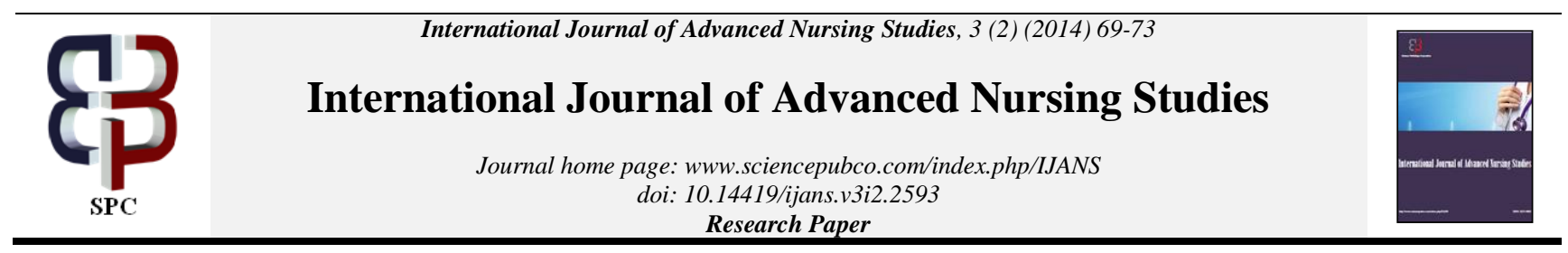

\title{
Assessment of healthy lifestyle habits among Mosul university students
}

\author{
Nasir M. Younis \\ College of Nursing, University of Mosul, Iraq \\ E-mail: nasir_younse@yahoo.com
}

\begin{abstract}
Background: A healthy lifestyle leaves you fit, energetic and at reduced risk for disease, based on the choices you make about your daily habits. Good nutrition, daily exercise and adequate sleep are the foundations for continuing good health. Managing stress in positive ways, instead of through smoking or drinking alcohol, reduces wear and tear on your body at the hormonal level. For a longer and more comfortable life, put together your plan for a healthy lifestyle and live up to it.

Objectives: This study was aimed to assess of Healthy lifestyle habits among Mosul University Students and to examine relationship between the university student's characteristics and healthy lifestyles habits.

Method: Cross-sectional survey design is applied to assess healthy lifestyle habit among Mosul University Students. Random sample consist of (400) students (Male and Female) were students in Mosul University from specialty difference (College of Medicine, College of Dentistry, College of Nursing, College of Pharmacy, College of Fine Arts, College of Education , College of Basic Education and College of Law),From end stage in University. Period of data collection first December 2013 extended from end February 2014. An interview technique method was used for data collection. Data were analyzed through the application of the descriptive and inferential statistical data analysis.

Results: The results of the study indicated that Mosul university students have a low score in the total healthy lifestyle habits, demonstrating that female are higher than that of male(56\%).

Conclusion: The study concluded that the results are accepted concerning healthy lifestyle habit among Mosul University. After completing this survey, the researcher found that a lot of university students had a big problem of their healthy lifestyle habits, especially eating habits such as they skip breakfast, eat snacks and drink tea a lot.
\end{abstract}

Keywords: Health, Lifestyle, Students, University.

\section{Introduction}

A healthy lifestyle leaves you fit, energetic and at reduced risk for disease, based on the choices you make about your daily habits. Good nutrition, daily exercise and adequate sleep are the foundations for continuing good health. Managing stress in positive ways, instead of through smoking or drinking alcohol, reduces wear and tear on your body at the hormonal level. For a longer and more comfortable life, put together your plan for a healthy lifestyle and live up to it.(Nancy Clarke,2013). The World Health Organization (WHO) has stated that $60 \%$ of an individual's health-related quality of life depends on his/her lifestyle (Ziglio et.al, 2004). Numerous publications (Othlings et.al, 2010)( Reddy, et.al, 2011) have shown that healthy lifestyle practices reduce disease occurrence and mortality rates and socio demographic dimensions such as sex, age, marital status, economical level and paid employment correlate with healthy lifestyle. University students represent the future decision makers in organizations, communities, and countries. University years are a period where students increasingly make independent choices about their lifestyle and health practices.(Lee et.al, 2005) However, the university period also encompasses stresses for students trying to achieve success in their academic goals despite the financial constraints that many report. Such stressors, in combination with experiences of 'freedom' from parental restrictions, might support the development of risky lifestyles e.g., high consumption of alcohol and drugs, and a low concern for healthy nutrition and restful sleep (El Ansari and Stock, 2010).Drug consumption, especially tobacco and alcohol, unsuitable diet and insufficient physical activity (PA) determine an important part of the deaths and illnesses that occur in the European region of the World Health Organization. These lifestyles are largely modifiable through political action, and it is interesting for public health to know their evolution and trends in different communities and population groups (WHO, 2009).Among these groups, the health habits of university students are a special concern, since they represent a major segment of the young population and they are at a stage of their lives during which important lifestyle modifications take place (Madureira et al 2009). If these changes become fixed routines, they are likely to determine the person's future health (Steptoe et al, 2002)(Von et al, 2005). This kind of research becomes especially necessary at university, since students make up a homogenous and accessible population, who also can generally be considered to be in relatively good health. The need to analyze health behavior from a gender perspective has been pointed out by some authors (Kelly-Weeder,2008) The gender differences among university students in health are a consequence of different structural contexts for genders (age, social support, and family arrangement), lifestyle (smoking, drinking, exercise, diet) and psychosocial fac- 
tors (critical life events, stress, and psychological resources) .It has been noted by some authors that women's health is more influenced by structural and psychosocial factors such as stress and lower levels of self-esteem and sense of coherence, while men's health was more affected by health behaviors such as smoking, drinking and physical activity (Denton et al, 2004). It has also been pointed out that it would be most convenient for the university population, especially for future health and education professionals, to develop and lead a healthy lifestyle, since they will be responsible for the encouragement of healthy habits among future generations (Steptoe et al, 2002).This fact has fostered research on university students' lifestyle, especially in those students who are doing a health-related university degree (Gaffney et al , 2002)(Fernandez et.al, 2010) However, to the author's knowledge, it seems that scientific research aimed to compare and identify healthy habits among university students, taking into account their gender and chosen academic discipline, are less frequent(Riou Franca et al, 2010)(Tirodimos et al, 2009). A significant amount of the mortality and morbidity experienced worldwide today is preventable(Eyre et al,2004).The major determinants of health are socioeconomic factors, lifestyle factors and the physical environment Lifestyle-related risk factors that were acknowledged in The European health report of the World Health Organization (WHO) included unhealthy nutrition, physical inactivity, tobacco use and the use of alcohol and illicit drugs(WHO,2005).Health-related behavior in early life influences later risks for lifestyle-related disorders. It is therefore important to investigate health behaviors among young people. University students represent a major segment of the young adult population. It makes sense to focus on them, for example in studies of the association between beliefs and practices for a healthy lifestyle, in order to design effective health promotion activities targeting this group(Steptoe, 2002). In parallel with the rapidly developing technology, eating habits also undergo changes. Although nutrition is important for all segments of the society, it is of a different importance for university students (Erten, 2006).Individuals, who gain independence in this period, start to decide on their eating preferences, to eat out more frequently and to get influenced by their circle of friends more Therefore, they tend to consume those foods that are deemed unhealthy such as fizzy drinks and fast food more (Demirezen, and ve, 2005). The Objective of the study to assess of healthy Life style habits among Mosul university students and to identify the association between some characteristics of the students with healthy lifestyle habits.

\subsection{Aims of the study}

The aim of this study was to assess of Healthy lifestyle habits among Mosul University Students.

\section{Methods}

\subsection{Design, setting and sample}

This study was conducted among Mosul university students, one of the public universities in Iraq. The target population was all university a student who met the sample criteria and agreed to participate in the study.Cross-sectional survey design was applied in the present study. Random sample consist of (400) students ( Male and Female ) were students in Mosul University from specialty difference (College of Medicine, College of Dentistry, College of Nursing, College of Pharmacy, College of Fine Arts, Col- lege of Education, College of Basic Education, College of Law). From end stage in University. Period of data collection first December 2013 extended from end February 2014.

\subsection{Instrument}

A self-administered questionnaire used for this study consisted of two main parts: Part I, The students' demographical data including: The age, gender, college, marital status, residential and health status ,Part II: Healthy lifestyle habits for students it content 20 items, A three - point liked scale option was used in the rating scale as:(3)for Always, (2) for sometimes and (1) for never .determination of healthy life style habits for University Students less 40 score poor, (40-49)score accepted and more 50 score good.

\subsection{Data analysis}

Data were analyzed using the Statistical Packages for the Social Sciences (SPSS-17.0) software using both descriptive and inferential statistics (SPSS 2007). The descriptive analysis used to describe the frequencies, , means, medians and standard deviations for the participant's characteristics and the healthy lifestyle habits for students as well as also used relative sufficiency and Chisquare .

\section{Results}

\subsection{Characteristics of participants}

As shown in Table 1, participants' demographics from all university of Mosul (400 participants) were compared to each other. Apparently, the majority of participants were female (56\%) .and most of them aged (18-27 or more years) years. In relation to their marital status, most of the whole sample were married and constituted $(65.75 \%)$. Regarding, their residence, most of the sample were urban $(87.5 \%)$.The highest in health status of sample were good health and constituted of $(61 \%)$.

Table 1: Demographic Characteristics of the Study Subjects ( $\mathrm{N}=400)$.

\begin{tabular}{lll}
\hline Variables & No. & Percentage (\%) \\
\hline (A) Gender & & \\
Male & 176 & $44 \%$ \\
Female & 224 & $56 \%$ \\
Total & 400 & $100 \%$ \\
(B) Age & & \\
18- 20 years & 17 & $4.25 \%$ \\
21-23 years & 287 & $71.75 \%$ \\
24-26years & 80 & $20 \%$ \\
27 years or more & 16 & $4 \%$ \\
(C) Marital status & & \\
Married & 263 & $65.75 \%$ \\
Single & 134 & $33.5 \%$ \\
Widowed & 3 & $0.75 \%$ \\
Total & 400 & $100 \%$ \\
(D) Residence & & \\
Urban & 350 & $87.5 \%$ \\
Rural & 50 & $12.5 \%$ \\
Total & 400 & $100 \%$ \\
(E) Heath status & & \\
Good & 244 & $61 \%$ \\
Moderate & 153 & $38.25 \%$ \\
Bad & 3 & $0.75 \%$ \\
Total & 400 & $100 \%$ \\
& &
\end{tabular}


Table 2: The Mean of Scores,Standard Deviation and Relative Sufficiency of Students Healthy Lifestyle Habits.

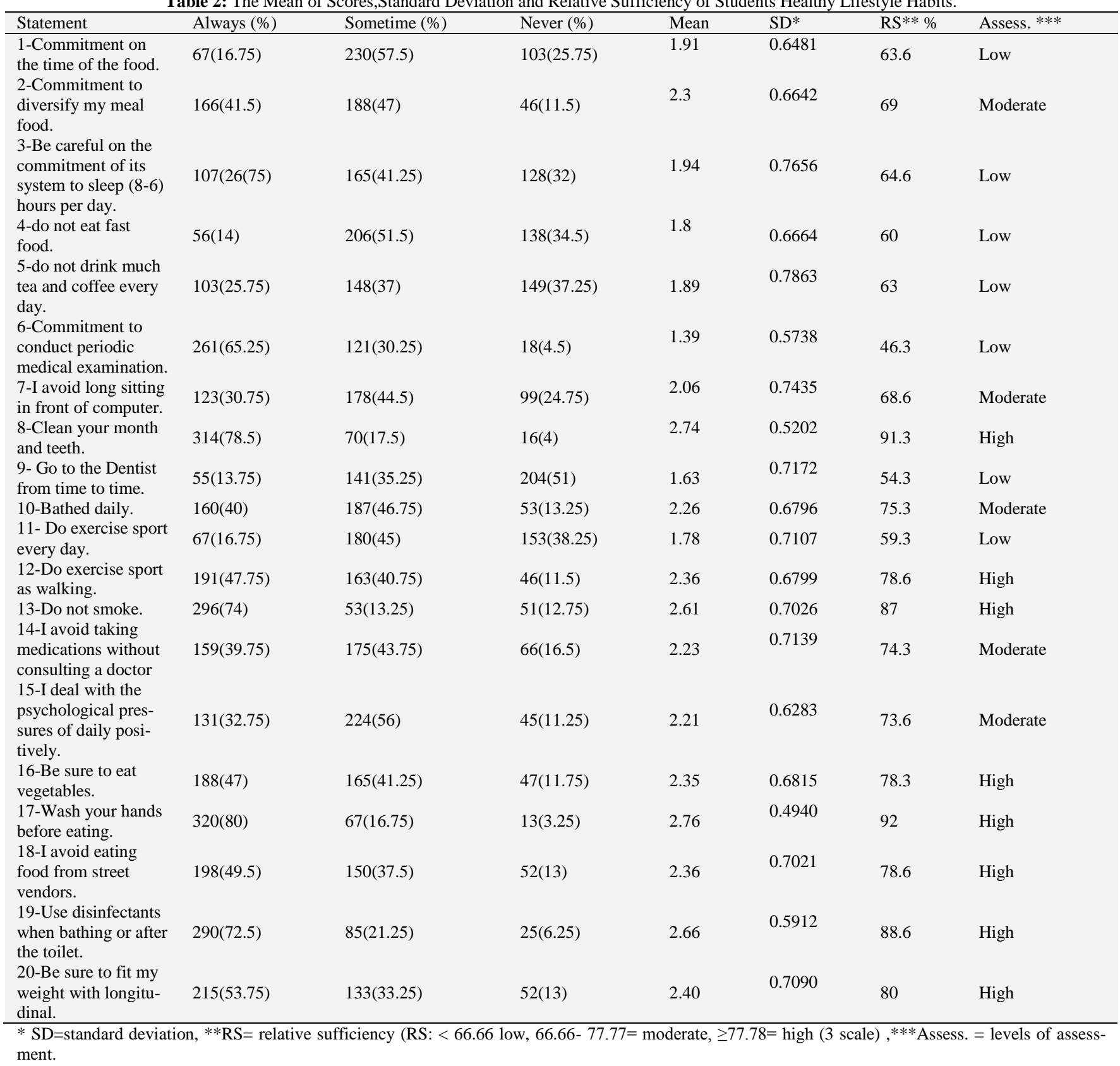

Table 2 presented the total means, standard deviation, and relative sufficiency of student's healthy lifestyle habits. Were of; the general health and vitality have low, commitment on the time of the food and commitment of its system to sleep (8-6) hours per day. While the personal hygiene, and psychological health has moderate, and the role exercise sport as walking and smoker habits, have high healthy life style.

Table 3: Determination of Healthy Life Style Habits for University Students.

\begin{tabular}{llll}
\hline College & $\begin{array}{l}\text { Poor }(\%) \\
<40\end{array}$ & $\begin{array}{l}\text { Accepted }(\%) \\
(40-49)\end{array}$ & $\begin{array}{l}\text { Good }(\%) \\
>50\end{array}$ \\
\hline College of Medicine & $7(14 \%)$ & $32(64 \%)$ & $11(22 \%)$ \\
College of Dentistry & $10(20 \%)$ & $36(72 \%)$ & $4(8 \%)$ \\
College of pharmacy & $18(36 \%)$ & $28(56 \%)$ & $4(8 \%)$ \\
$\begin{array}{l}\text { College of Nursing } \\
\text { College of Educa- }\end{array}$ & $5(10 \%)$ & $38(76 \%)$ & $7(14 \%)$ \\
tion & $13(26 \%)$ & $36(72 \%)$ & $1(2 \%)$ \\
College of Basic & & & \\
Education & $8(16 \%)$ & $35(70 \%)$ & $7(14 \%)$ \\
College of Law & $13(26 \%)$ & $30(60 \%)$ & $7(14 \%)$ \\
College of Fine Arts & $8(16 \%)$ & $35(70 \%)$ & $7(14 \%)$ \\
Total & $82(20.50 \%)$ & $270(67.50 \%)$ & $48(12 \%)$ \\
\hline
\end{tabular}

Table 4: Association between Students Gender and Their Healthy Life Style Habits Scores.

\begin{tabular}{|c|c|c|c|c|c|c|}
\hline $\begin{array}{l}\text { Score } \\
\text { Gen- } \\
\text { der } \\
\end{array}$ & No & $\begin{array}{l}\text { Poor }(\%) \\
<40\end{array}$ & $\begin{array}{l}\text { Accepted } \\
(\%) \\
(40-49) \\
\end{array}$ & $\begin{array}{l}\text { Good }(\%) \\
>50\end{array}$ & $\begin{array}{l}\chi^{2} \\
\text { obs. }\end{array}$ & Sig \\
\hline \multirow{2}{*}{ Male } & 17 & 51 & $106(60.22 \%$ & $19(10.80 \%$ & \multirow{4}{*}{$\begin{array}{l}16.95 \\
3\end{array}$} & \multirow{4}{*}{ HS } \\
\hline & 6 & $(28.98 \%)$ & ) & ) & & \\
\hline $\mathrm{Fe}-$ & 22 & $28(12.5 \%$ & $164(73.22 \%$ & $32(14.28 \%$ & & \\
\hline male & 4 & ) & ) & ) & & \\
\hline $\mathrm{P} \leq 0.05$ & & $\mathrm{df}=2$ & $\chi^{2}$ crit. & 5.99 & & \\
\hline
\end{tabular}

The findings of table 4 presented that there were high significant association between student's gender and their healthy life style habits Scores 
Table 5: Association between Students Age and Their Healthy Life Style Habits Scores.

\begin{tabular}{|c|c|c|c|c|c|c|}
\hline $\begin{array}{l}\text { Score } \\
\text { Age }\end{array}$ & No & $\begin{array}{l}\text { Poor }(\%) \\
\text { NS }<40\end{array}$ & $\begin{array}{l}\text { Accepted } \\
(\%) \\
(40-49)\end{array}$ & $\begin{array}{l}\text { Good }(\%) \\
>50\end{array}$ & $\begin{array}{l}\chi^{2} \\
\text { obs. }\end{array}$ & Sig. \\
\hline $\begin{array}{l}18-20 \\
\text { years }\end{array}$ & 17 & $2(11.76 \%)$ & $13(76.48 \%)$ & $2(11.76 \%)$ & \multirow{5}{*}{7.020} & \multirow{5}{*}{ NS } \\
\hline $21-23$ years & 287 & $52(18.12 \%)$ & $194(67.60 \%)$ & $41(14.28 \%)$ & & \\
\hline 24-26years & 80 & $21(26.25 \%)$ & $54(67.5 \%)$ & $5(6.25 \%)$ & & \\
\hline $\begin{array}{l}27 \text { years or } \\
\text { more }\end{array}$ & 16 & $4(25 \%)$ & $9(56.25 \%)$ & $3(18.75 \%)$ & & \\
\hline $\mathrm{P} \leq 0.05$ & \multicolumn{2}{|c|}{$\mathrm{df}=6$} & $\chi^{2}$ crit. $=12.59$ & & & \\
\hline
\end{tabular}

This table indicates that there is no significant association between student's age and their healthy life style habits Scores at $\mathrm{P} \leq 0.05$. And this table also revealed $(26.25 \%)$ of the sample aged between (24-26years) has poor score.

Table 6: Association between Students Residence and Their Healthy Life Style Habits Scores.

\begin{tabular}{|c|c|c|c|c|c|c|}
\hline $\begin{array}{l}\text { Score } \\
\text { Residence }\end{array}$ & No & $\begin{array}{l}\text { Poor }(\%) \\
<40\end{array}$ & $\begin{array}{l}\text { Accepted } \\
(\%) \\
(40-49)\end{array}$ & $\begin{array}{l}\text { Good }(\%) \\
>50\end{array}$ & $\begin{array}{l}\chi^{2} \\
\text { obs. }\end{array}$ & Sig. \\
\hline Urban & 350 & $67(19.14 \%)$ & $236(67.43 \%)$ & $47(13.43 \%)$ & \multirow{3}{*}{1.536} & \multirow{3}{*}{ NS } \\
\hline Rural & 50 & $12(24 \%)$ & $34(68 \%)$ & $4(8 \%)$ & & \\
\hline $\mathrm{P} \leq 0.05$ & \multicolumn{2}{|c|}{$\mathrm{df}=2$} & $\chi^{2}$ crit. $=5.99$ & & & \\
\hline
\end{tabular}

This table shows that there is no significant association between student's residence and their healthy life style habits Scores at $\mathrm{P} \leq 0.05$.

Table (7): Association between Students Health Status and Their Healthy Life Style Habits Scores.

\begin{tabular}{|c|c|c|c|c|c|c|}
\hline $\begin{array}{l}\text { Score } \\
\text { Health } \\
\text { status }\end{array}$ & No & $\begin{array}{l}\text { Poor }(\%) \\
<40\end{array}$ & $\begin{array}{l}\text { Accepted } \\
(\%) \\
(40-49) \\
\end{array}$ & $\begin{array}{l}\text { Good }(\%) \\
>50\end{array}$ & $\begin{array}{l}\chi^{2} \\
\text { obs. }\end{array}$ & Sig. \\
\hline Good & 244 & $47(19.26 \%)$ & $157(64.34 \%)$ & $40(16.40 \%)$ & \multirow{4}{*}{7.901} & \multirow{3}{*}{ NS } \\
\hline Moderate & 153 & $31(20.26 \%)$ & $111(72.55 \%)$ & $11(7.19 \%)$ & & \\
\hline $\mathrm{Bad}$ & 3 & $1(33.33 \%)$ & $2(66.67 \%)$ & $0(0 \%)$ & & \\
\hline $\mathrm{P} \leq 0.05$ & \multicolumn{2}{|c|}{$\mathrm{df}=4$} & crit. $=9.49$ & & & \\
\hline
\end{tabular}

This table reflects that there is no significant association between students Health status and their healthy life style habits score at $\mathrm{P} \leq 0.05$. And this table also revealed $(33.33 \%)$ of the study sample the health status has poor score.

\section{Discussion}

Before considering the implications of our findings, several limitations in the data must be acknowledged. This sample of university students is not representative of the whole population and therefore caution in generalization of the results is necessary. University students are younger and better educated than the whole population, and lifestyle behaviors in terms of smoking, eating poorly and being physically inactive do not show an effect on health in a short time perspective. A sedentary lifestyle is a common and serious problem among university students. Compared to young adults in general, the pressure of work is so severe for university students that much of their time and energy is likely to be occupied with their studies. On the other hand, the popularization of computers and the Internet may provide more choices of entertainment and reduce interest in exercise. Lack of exercise facilities is also a major reason why university students do not participate actively in exercise. The majority of the participants answered they eat outside might be that most of them live off-campus and they have no time and equipment to prepare for their meals, so they usually eat off-campus in snack bar. The study findings indicated that Mosul university students have a low score in the total healthy lifestyle habits. However, the university students scored moderate in the personal hygiene, and interpersonal relations, and low in the physical activity, nutrition, and sleep habits. Low physical activity could be attributed to the Iraq perception about physical activity, in which they are not considering physical activity a part of their daily routine. Also, accessibility to sport and exercise facilities is not easy and fitness centers and swimming pools charge moderately high prices. Moreover, the lack of exercise and sport facilities might contribute to the problem of physical inactivity (Bothmer \& Fridlund 2005). Other potential reasons for students not exercising include heavy study load at university and the need for significant home study (Can et al. 2008). In addition, the prevalence of computers and the internet services may reduce interest in sport and exercise activities and provide other alternatives of entertainment for the students. The study findings revealed that students score average of nutrition behavior was low . Also, the results of this study indicated that university students did not demonstrate compliance with the recommended nutritional servings. For example, in this study, only $16.75 \%$ of participants reported that they limit Commitment on the time of the food. each day and $41.5 \%$ Commitment to diversify my meal food. Of concern are food eating patterns of university students because they have a tendency to skip meals frequently, eating "fast" foods and snacks. This may be understandable because students eat in the university cafeteria where the time of eating service is fixed and short, and food selection is limited (Wang et al. 2009).The current study indicated that Wash your hands before eating. And avoid eating food from street vendors. Was ranked the first highest among healthy lifestyle behaviors. the causes may be the influence of the culture and belief system of Iraqi society might help to maintain personal hygiene, as higher percentage in healthy life style habits among Mosul university, Table (2).Our study shows that the highest percentage accepted between university student in College of Nursing about $(76 \%)$ rather than other college and more student healthy lifestyle habits is good found College of Medicine about $(22 \%)$. This result is in agreement with study by (Wang et .al, 2009)in China found the all aspects of healthy lifestyle, the university students in the medical university are better than colleges and comprehensive university, which may be because training of medical curriculums make the medical students pay more attention to adopt healthy lifestyle. This result is similar with study by (Can et al. 2008) in Turkey mentioned that the nursing students had more positive health-promoting lifestyles than those of the non-nursing students. The result also suggests the importance of health education for university students which aims to promote healthy lifestyle, as shown in Table (3).This study found the healthy habits among woman are slightly higher than man $(56 \%)$. Previous study by Tirodimos et al, (2009) in Greek is agreement with this study, indicated that the healthy lifestyle habits Greek university students women (53\%) man (47\%). The results are in agreement with the study of Verónica and others in Spanish (2012) found highest in female $(51.8 \%)$ male $(48.2 \%)$, Table (4).Young adults between twenty and thirty years old are at their peak of their physical development. They enjoy more muscle tissue, more calcium in the bones, more brain mass, better sensory acuity, greater aerobic capacity, and more efficient immune system. They are the least likely to make use of health services when compared to children or older adults. About three quarter of the university students who aged between (18-23 years) that because the researchers are selected of the study sample from final stage in university, Table (5). This study indicated that the majority of student who live in urban area $(87.5 \%)$, because natural demographical for Mosul University, Table (6) .Ninety percent of the respondents reported that they feel healthy and that they did not miss more than one week of lectures because of physical complaints during the past semester and did not have any chronic disease .because routine screening was applying for all students before registration in university. Table (7). From the health educator's perspective, universities and colleges represent the final opportunity for the health and nutritional education of a large number of students. Our study adds information on students' lifestyle in Mosul in comparison with colleges others. A detailed knowledge of lifestyles and health needs in students is essential and may help to plan more effective interventions in this setting. 


\section{Conclusion}

The study concluded that the results accepted healthy lifestyle habit for everyone. After completing this survey, the researcher found that a lot of university students had a big problem of their healthy lifestyle habits, especially eating habits such as they skip breakfast, eat snacks and drink tea is more and Physical inactivity and smoking are risk factors found to significant extent amongst Mosul university students. This situation seems to be more conspicuous in men. Although there have been clear differences established in terms of lifestyle between genders .The findings of this study clearly state that there is a need to foster gendersensitive strategies to promote a healthy lifestyle among university students.

\section{Recommendations}

An education program can be designed, conducted and implemented to the university students concerning healthy lifestyle habits and Health education course should contain topics of healthy lifestyle habits e.g. Good nutrition, daily exercise and adequate sleep are the foundations for continuing good health which can be presented to these students .In addition Further and nationwide studies can be conducted on large sample size of students.

\section{Acknowledgement}

The author is grateful for the students who gave their time to contribute to this study.

\section{References}

[1] Bothmer M \& Fridlund B (2005). Gender differences in health habit and in motivation for a healthy lifestyle among Swedish university students. Nursing and Health Sciences, 7, 107-118.

[2] Can G, Ozdilli K, Erol O, Unsar S, Tulek Z, Savaser S, et al (2008). Comparison of the health-promoting lifestyles of nursing and nonnursing students in Istanbul, Turkey. Nursing and Health Sciences, 10 273-280.

[3] Demirezen, E. and ve G. Cosansu, 2005 Adolesancagiogrencilerindebeslenmealiskanliklarinindegerlendirilmes i. Sted, 14: 174-178.

[4] Denton, M.; Prus, S.; Walters, V. Gender differences in health: A Canadian study of the psychosocial, structural and behavioural determinants of health. Soc. Sci. Med. 2004, 58, 2585-2600.

[5] El Ansari W, Stock C. (2010) Is the health and wellbeing of university students associated with their academic performance? Cross sectional findings from the United Kingdom. Int J Environ Res Public Health; 7(2):50927.

[6] Erten,M.,2006.Adiyamanilindeegitimgorenuniversiteogrencilerininbes lenmebilgilerininvealiskanliklarininarastirilmasi. GaziUniversitesi, YuksekLisansTezi (basilmamis), 106s. Ankara.

[7] Eyre H, Kahn R, Robertson RM. Preventing cancer, cardiovascular disease, and diabetes: a common agenda for the American Cancer Society, the American Diabetes Association, and the American Heart Association. Circulation, 2004, 109:3244-55.

[8] Fernandez, D.; Martin, V.; Molina, A.J.; de Luis, J.M. Smoking habits of students of nursing: A questionnaire survey (2004-2006). Nurse Educ. Today 2010, 30, 480-484.

[9] Gaffney, K.F.; Wichaikhum, O.A.; Dawson, E.M. (2002), Smoking among female college students: A time for change. J. Obstet. Gynecol Neonatal Nurs. 31, 502-507.

[10]Kelly-Weeder, S. (2008) Binge drinking in college-aged women: Framing a gender-specific prevention strategy. J. Am. Acad. Nurse Pract., 20, 577-584.

[11]Lee DH, Kang S, and Zum S.(2005)A qualitative assessment of personal and academic stressors among Korean Collage students: an exploratory study. College Student Journal:39(3):442.

[12]Madureira, A.S.; Corseuil, H.X.; Pelegrini, A.; Petroski, E.L. (2009) Association between stages of behavior change related to physical activity and nutritional status in university students. Cad. Saude Publ. 25 , 2139-2146.
[13]Nancy Clarke Oct, 21, 2013. Definition of Healthy lifestyle. www.Livestrong.com. By .Nancy Clarke.

[14]Othlings U. N, Ford, J. E. oger, K .r and. Boeing, H. (2010) "Lifestyle factors and mortality among adults with diabetes: findings from the European Prospective Investigation into Cancer and NutritionPotsdam study,'Journal of Diabetes, vol. 2, no. 2, pp. 112-117.

[15]Reddy, P. Rankins, D. Timoshanko, A. and Dunbar, J. A. (2011) "Life! In Australia: translating prevention research into a large-scale intervention," British Journal of Diabetes and Vascular Disease, vol. 11, no. 4, pp. 193-197.

[16]Riou Franca, L.; Dautzenberg, B.; Falissard, B.; Reynaud, M. Peer substance use overestimation among French university students: A cross-sectional survey. BMC Public Health 2010, 10, doi: 10.1186/1471-2458-10-169.

[17] Steptoe A. Trends in smoking, diet, physical exercise, and attitudes toward health in European university students from 13 countries, 1990-2000. Preventive medicine, 2002, 35:97-104.

[18] Steptoe, A.; Wardle, J.; Cui, W.; Bellisle, F.; Zotti, A.M.; Baranyai, R.; Sanderman, R. Trends in smoking, diet, physical exercise, and attitudes toward health in European University students from 13 countries, 1990-2000. Prev. Med. 2002, 35, 97-104.

[19]The European health report 2002. Copenhagen, World Health Organization Regional Office for Europe, 2005 (European Series, No. 97).

[20]Tirodimos, I.; Georgouvia, I.; Savvala, T.N.; Karanika, E.; Noukari, D.(2009), Healthy lifestyle habits among Greek university students: Differences by gender and faculty of study 3 . East Mediterr. Health J. $15,722-728$

[21]Verónica Varela-Mato, José M. Cancela, Carlos Ayan, Vicente Martín and Antonio Molina. (2012), Lifestyle and Health among SpanishUniversity Students: Differences by Gender and Academic Discipline. Int. J. Environ. Res. Public Health, 9, 2728-2741.

[22]Von Bothmer, M.I.; Fridlund, B. (2005) Gender differences in health habits and in motivation for a healthy lifestyle among Swedish University students. Nurs. Health Sci, 7, 107-118.

[23]Wang D, Ou CQ, Chen MY, \& Duan N (2009). Health-promoting lifestyles of university students in Mainland China. BMC Public Health, 9,379. Doi: 10.1186/1471-2458-9-379.

[24] World Health Organization (WHO). The European Health Report 2009: Health and Health Systems; WHO Regional Office for Europe Copenhagen, WHO: Copenhagen, Denmark, 2009.

[25]Ziglio, E. Currie, C. and Rasmussen, V. B. "The WHO crossnational study of health behavior in school-aged children from 35 countries: findings from2001-200"Journal of School Health, vol. 74, no. 6, pp. 204-206, 2004 